\title{
Rhodium Complexes of Sterically Demanding Diphosphonites: Coordination Chemistry and Catalysis
}

\author{
J arl Ivar van der Vlugt, ${ }^{\dagger}$ Rafaël Sablong, ${ }^{\dagger}$ Pieter C. M. M. Magusin, ${ }^{\dagger}$ \\ Allison M. Mills, ${ }^{\ddagger}$ Anthony L. Spek, ${ }^{\ddagger}$ and Dieter Vogt*, \\ Schuit Institute for Catalysis, Laboratory for Homogeneous Catalysis, Eindhoven \\ University of Technology, Den Dolech 2, 5600 MB Eindhoven, The Netherlands, and \\ Department of Crystal and Structural Chemistry, Utrecht University, \\ Padualaan 8, $3584 \mathrm{CH}$ Utrecht, The Netherlands
}

Received February 11, 2004

\begin{abstract}
The coordination chemistry of various sterically constrained diphosphonites $\mathbf{1}-\mathbf{6}$ with rhodium are reported. The stoichiometric reaction of ligand $\mathbf{5}$ with $\left[\mathrm{Rh}\left(u-\mathrm{Cl}(\mathrm{CO})_{2}\right]_{2}\right.$ gives rise to the sole formation of trans-[RhCl(CO)(5)] (7), as shown by NMR and IR spectroscopy and X-ray crystallography. The molecular structure reveals a weak interaction between the metal center and the oxygen from the xanthene backbone. This complex serves as a structural model for the first intermediate in the catalytic cycle of rhodium hydroformylation, $[R h(H)$ $\left.(\mathrm{CO})\left(\mathrm{P}^{-} \mathrm{P}\right)\right]$. A detailed study on the solution structure of the catalyst resting state under catalytic conditions is performed by high-pressure NMR and FT-IR spectroscopy. The spectroscopic data show that under hydroformylation conditions the bidentate ligands form well-defined complexes with the structure $\left[\mathrm{Rh}(\mathrm{H})(\mathrm{CO})_{2}\left(\mathrm{P}^{\prime} \mathrm{P}\right)\right]$. All ligands show preference for a bis-equatorial (ee) coordination mode in the trigonal-bipyramidal Rh complexes. These novel sterically constrained diphosphonite ligands are applied in the rhodium hydroformylation of 1-octene and 2-butene, and good activities and regioselectivities are obtained.
\end{abstract}

\section{Introduction}

The hydroformylation of alkenes is probably the best known example of homogeneous catalysis performed on a large industrial scale, employing rhodium catalysts. ${ }^{1-3}$ In academia as well as in industrial research the selective production of long-chain aldehydes such as 1-nonanal, which is obtained by hydroformylation of 1-octene, is an area of continuous attention. Such compounds find application in, for example, the production of detergent alcohols. ${ }^{4}$ The worldwide annual oxo capacity was $6.6 \times 10^{6}$ tons in 1995, which reached up to $9.2 \times 10^{6}$ tons in $19988^{4,5}$ In the past few decades, several new classes of especially large bite angle ligands have been developed. The plethora of these chelating ligands are based on diphosphines ${ }^{6-10}$ or diphosphites, ${ }^{11-16}$ but also some monophosphines and mono-

* To whom correspondence should be addressed. E-mail: d.vogt@ tue.nl. Tel: +31 (0)40 2472483. Fax: +31(0)40 2455054.

† Eindhoven University of Technology.

₹ Utrecht University.

(1) Tolman, C. A.; Faller, J . W. In Homogeneous Catalysis with Metal Phosphine Complexes; Pignolet, L. H., Ed.; Plenum: New York, 1983, p 81.

(2) Beller, M.; Cornils, B.; Frohning, C. D.; Kohlpainter, C. W. J . Mol. Catal. A: Chem. 1995, 104, 17.

(3) Frohning, C. D.; Kohlpainter, C. W.; Bohnen, H. W. In Applied Homogeneous Catalysis with Organometallic Compounds; Cornils, B., Herrmann, W. A., Eds.; Wiley-VCH: Weinheim, Germany, 2002; Vol. $1, \mathrm{p} 31$.

(4) Arnoldy, P. In Rhodium Catalyzed Hydroformylation; van Leeuwen, P. W. N. M., Claver, C., Eds.; Kluwer: Amsterdam, 2000; p 203.

(5) Bohnen, H. W.; Cornils, B. Adv. Catal. 2002, 47, 1.

(6) (a) Devon, T. J .; Phillips, G. W.; Puckette, T. A.; Stavinoha, J L.: Vanderbilt, 」. I . (to Eastman Kodak) U.S. Patent 4,694,109, 1987; Chem. Abstr. 1987, 108, 7890. (b) Devon, T. J ; Phillips, G. W.; Puckette, T. A.; Stavinoha, J . L.; Vanderbilt, J . J . (to Eastman Kodak) U.S. Patent 5,332,846, 1994; Chem. Abstr. 1994, 121, 280879. phosphites have been reported. ${ }^{17,18}$ In the design of new ligand classes, a modular approach combined with a thorough understanding of their coordination chemistry is essential. Recently, xanthene and derivatives thereof have proven to be very suitable backbones for the synthesis of rigid phosphorus ligands with various applications in homogeneous catalysis. ${ }^{9}$ So far only the diphosphine (A) ${ }^{19}$ and diphosphite $(\mathbf{B})^{20}$ derivatives (Figure 1)

(7) Casey, C. P.; Whiteker, G. T.; Melville, M. G.; Petrovich, L. M. Gavney, J. A., J r.; Powell, D. R. J . Am. Chem. Soc. 1992, 114, 5535.

(8) Bahrmann, H.; Lappe, P.; Herrmann, W. A.; Albanese, G. P.; Manetsberger, R. B. (to Hoechst AG) Eur. Patent 646,588, 1995; Chem. Abstr. 1995, 123, 112408.

(9) Kamer, P. C. J ; Reek, J . N. H.; van Leeuwen, P. W. N. M. Acc. Chem. Res. 2001, 34, 895.

(10) (a) Ahlers, W.; Paciello, R.; Vogt, D.; van der Vlugt, I. I. (to BASF AG) U.S. Patent 6,639,114; 2002; Chem. Abstr. 2002, 137 169060. (b) van der Vlugt, J . I.; Bonet, J . M.; Mills, A. M.; Spek, A. L.; Vogt, D. Tetrahedron Lett. 2003, 44, 4389. (c) van der Vlugt, J . I.; Grutters, M. M. P.; Mills, A. M.; Spek, A. L.; Vogt, D. Eur. J . Inorg. Chem. 2003, 4361.

(11) Billig, E.; Abatjoglou, A. G.; Bryant, D. R. (to Union Carbide) U.S. Patent 4,769,498, 1988; Chem. Abstr. 1988, 111, 117287.

(12) Sato, K.; Karawagi, Y.; Takai, M.; Ookoshi. T. (to Mitsubishi) Eur. Patent 518,241, 1992; Chem. Abstr. 1992, 118, 191183.

(13) van Rooy, A.; Kamer, P. C. J .; van Leeuwen, P. W. N. M.; Goubitz, K.; Fraanje, J .; Veldman, N.; Spek, A. L. Organometallics 1996, 15, 835

(14) Paciello, R.; Siggel, L.; Röper, M. Angew. Chem., Int. Ed. 1999, 38, 1920.

(15) Kunze, C.; Selent, D.; Neda, I.; Schmutzler, R.; Spannenberg, A.; Börner, A. Heteroatom Chem. 2001, 12, 577.

(16) van der Vlugt, J. I.; Ackerstaff, J.; Dijkstra, T. W.; Mills, A M.; Kooijman, H.; Spek, A. L.; Meetsma, A.; Abbenhuis, H. C. L.; Vogt, D. Adv. Synth. Catal., in press.

(17) Kamer, P. C. J .; Reek, J . N. H.; van Leeuwen, P. W. N. M. In Rhodium Catalyzed Hydroformylation; van Leeuwen, P. W. N. M., Claver, C., Eds.; Kluwer: Dordrecht, The Netherlands, 2000; p 35.

(18) van der Vlugt, J . I.; Grutters, M. M. P.; Ackerstaff, J .; Hanssen, R. W. J . M.; Abbenhuis, H. C. L.; Vogt, D. Tetrahedron Lett. 2003, 44, 8301. See also ref 16 
<smiles>CC1(C)c2cccc(P)c2Oc2c(-c3ccccc3)cccc21</smiles>

A<smiles>[R]c1cc(C(C)(C)C)c2op(Oc3cccc4c3Oc3c(Op5oc6c(C(C)(C)C)cc([R])cc6c6cc([R])cc(C(C)(C)C)c6o5)cccc3C4(C)C)oc3c(C(C)(C)C)cc([R])cc3c2c1</smiles>

Figure 1. Xanthene based diphosphine $(A)$ and diphosphite (B) ligands.

of this family of compounds have been applied in the rhodium-catalyzed hydroformylation of alkenes. Furthermore, we have previously shown that simple xanthene-derived (chiral) diphosphonites can be applied in the nickel-catalyzed (asymmetric) hydrocyanation. ${ }^{21}$

To the best of our knowledge only one report, by Schmutzler and Börner, has appeared on the use of diphosphonites in the rhodium-catalyzed hydroformylation of alkenes, but only low regioselectivities, with $1: b$ ratios of $64: 36$ at the maximum, were obtained for 1-octene. 22 Börner et al . also reported on the application of monophosphonites in the hydroformylation of 1-octene and 4-octene. ${ }^{23}$ We were therefore interested to develop a class of diphosphonites suitable for use in these reactions. Here we wish to report on the coordination chemistry of our novel class of sterically constrained diphosphonites (Figure 2) to rhodium, with emphasis on a spectroscopic investigation of the catalytic resting state under hydroformylation conditions. We will discuss the results obtained with these bulky ligands in the rhodium-catalyzed hydroformylation of 1-octene and preliminary results for the isomerizing hydroformylation of 2-butene.

\section{Results and Discussion}

Diphosphonites 1-6 and Synthesis of the Chlorocarbonylrhodium(I) Complex 7. In this work a series of ligands based on xanthene and phenoxathiin backbones (Figure 2 ) is employed. The straightforward two-step synthesis of these compounds will be reported in detail el sewhere, ${ }^{24}$ together with their characterization and use in hydrocyanation and isomerization reactions. In short, these compounds can be obtained in two

(19) (a) Hillebrand, S.; Bruckmann, J : Krüger, C.; Haenel, M. W Tetrahedron Lett. 1995, 36, 75. (b) Kranenburg, M.; van der Burgt, Y. E. M.; Kamer, P. C. J ; van Leeuwen, P. W. N. M.; Goubitz, K.; Fraanje J . Organometallics 1995, 14, 3081. (c) van der Veen, L. A.; Boele, M D. K.; Bregman, F. R.; Kamer, P. C. J .; van Leeuwen, P. W. N. M. Goubitz, K.; Fraanje, J .; Schenk, H.; Bo, C. J . Am. Chem. Soc. 1998, 120, 11616.

(20) (a) Hewat, A. C. Ph.D. Dissertation, RWTH Aachen, 2001 (under supervision of Keim and Vogt). (b) Dieleman, C. B.; Kamer, P. C. J.; Reek, J. N. H.; Leeuwen, P. W. N. M. Helv. Chim. Acta 2001, 84, 3269 .

(21) Goertz, W.; Kamer, P. C. J .; van Leeuwen, P. W. N. M.; Vogt, D. Chem. Eur. J . 2001, 7, 1614.

(22) Kunze, C.; Selent, D.; Neda, I.; Freytag, M.; J ones, P. G.; Schmutzler, R.; Baumann, W.; Börner, A. Z. Anorg. Allg. Chem. 2002, 628, 779.

(23) Selent, D.; Wiese, K.-D.; Röttger, D.; Börner, A. Angew. Chem., Int. Ed. 2000, 39, 1639.

(24) (a) Ahlers, W.; Wiebelhaus, D.: Paciello, R.; Bartsch, M.; Baumann, R.; Vogt, D.; Hewat, A. C. (to BASF AG) WO 02/22261, 2002 Chem. Abstr. 2002, 136, 249480. (b) van der Vlugt, J . I.; Hewat, A. C.; Neto, S.; Sablong, R.; Mills, A. M.; Lutz, M.; Spek, A. L.; Müller, C.; Vogt, D. Adv. Synth. Catal. 2004, 346, 399.

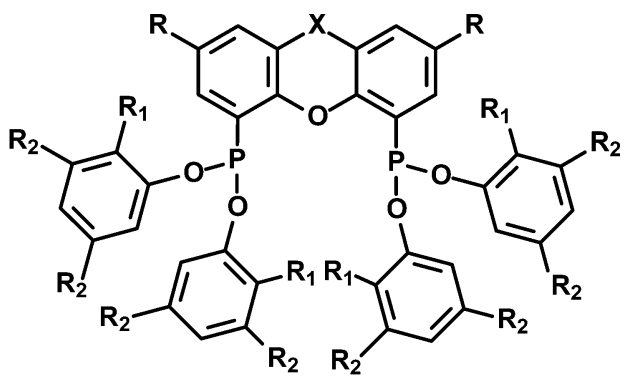

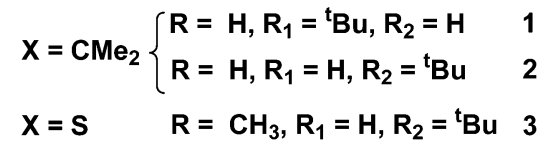

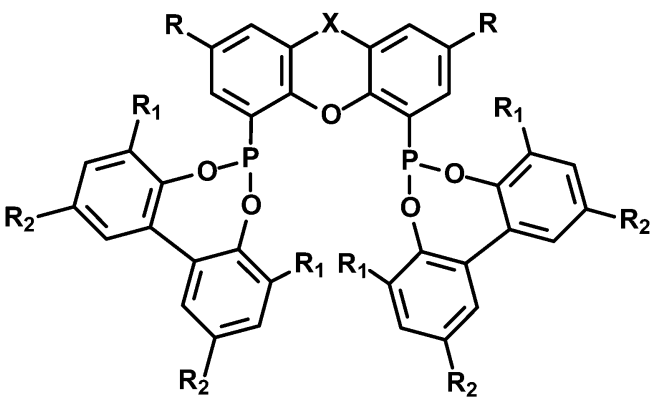

$$
\begin{aligned}
& X=\mathrm{CMe}_{2} \begin{cases}\mathrm{R}=\mathrm{H}, \mathrm{R}_{1}={ }^{\mathrm{t}} \mathrm{Bu}, \mathrm{R}_{2}={ }^{\mathrm{t}} \mathrm{Bu} & 4 \\
\mathrm{R}=\mathrm{H}, \mathrm{R}_{1}={ }^{\mathrm{t} B u}, \mathrm{R}_{2}=\mathrm{OMe} & 5\end{cases} \\
& \mathrm{X}=\mathrm{S} \quad \mathrm{R}=\mathrm{CH}_{3}, \mathrm{R}_{1}={ }^{\mathrm{t} B u}, \mathrm{R}_{2}=\mathrm{OMe}^{6}
\end{aligned}
$$

Figure 2. Novel sterically demanding xanthene based diphosphonite ligands.

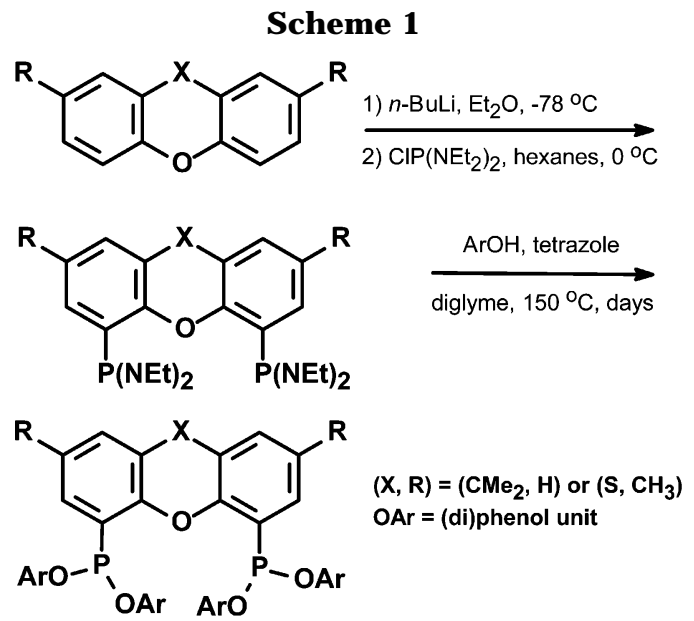

reaction steps in good yields from commercially available reagents (Scheme 1). First, sel ective ortho lithiation of either 9,9-dimethylxanthene or 2,7-dimethyl phenoxathiin with n-BuLi and subsequent reaction with CIP$\left(\mathrm{NEt}_{2}\right)_{2}$ led to the bis(diethylaminophosphine) intermediates. These compounds were reacted with the appropriate bis(phenol) in the presence of tetrazole in a highboiling solvent such as diglyme to yield the desired diphosphonites 1-6, after recrystallization from toluene/ ethanol. 24

To assess these sterically demanding diphosphonites for their capability to coordinate to rhodium as a chelate ligand, we studied the reaction of $\left[\mathrm{Rh}(\mu-\mathrm{Cl})(\mathrm{CO})_{2}\right]_{2}$ with 2 equiv of ligand $\mathbf{5}$ as a representative example. The reaction proceeded smoothly overnight at room 


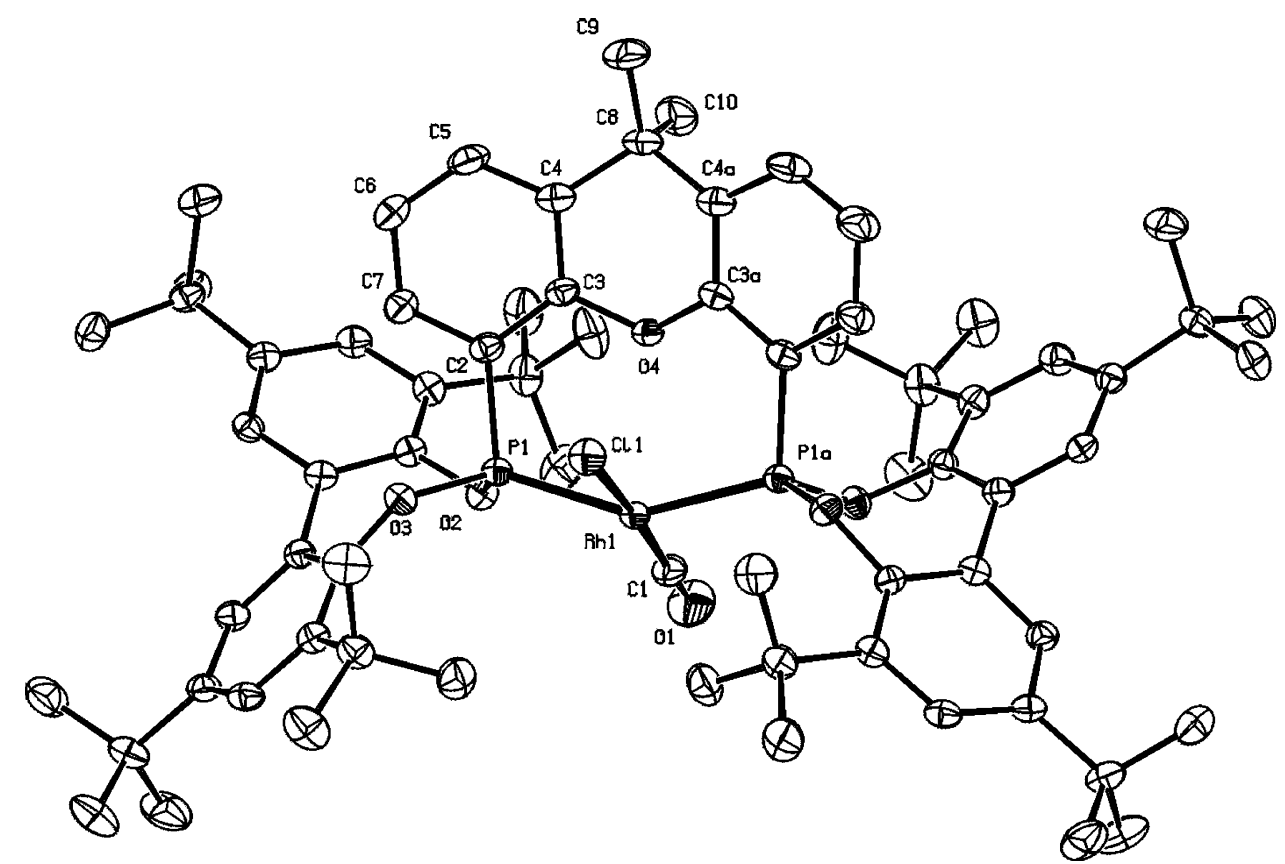

Figure 3. ORTEP representation of complex 7, trans-[RhCl(CO)(5)]. Displacement ellipsoids are drawn at the $50 \%$ probability level. All hydrogen atoms are omitted for clarity. Bond lengths $(\AA)$ and angles (deg): Rh- $P_{1}, 2.2567(5) ; R h-$ $\mathrm{P}_{1 a}, 2.2567(5) ; \mathrm{Rh}-\mathrm{Cl}, 2.3875(7) ; \mathrm{Rh}-\mathrm{C}_{1}, 1.826(3) ; \mathrm{C}_{1}-\mathrm{O}_{1}, 1.142(4) ; \mathrm{P}_{1}-\mathrm{O}_{2}, 1.6305(13) ; \mathrm{P}_{1}-\mathrm{O}_{3}, 1.6202(13) ; \mathrm{P}_{1}-\mathrm{C}_{2}, 1.8348-$ (19); $\mathrm{P}_{1}-\mathrm{P}_{1 a}$, 4.3534(7); $\mathrm{Rh}-\mathrm{O}_{4}, 2.7091(17) ; \mathrm{P}_{1}-\mathrm{Rh}-\mathrm{P}_{1 \mathrm{a}}, 149.40(2) ; \mathrm{Cl}_{1}-\mathrm{Rh}-\mathrm{C}_{1}, 174.56(8) ; \mathrm{P}_{1}-\mathrm{Rh}-\mathrm{Cl}_{1}, 87.23(1) ; \mathrm{P}_{1}-\mathrm{Rh}-$ $\mathrm{C}_{1}, 94.17(2) ; \mathrm{Rh}-\mathrm{C}_{1}-\mathrm{O}_{1}, 178.8(2) ; \mathrm{Rh}-\mathrm{P}_{1}-\mathrm{O}_{2}, 114.02(5) ; \mathrm{Rh}-\mathrm{P}_{1}-\mathrm{O}_{3}, 124.20(5) ; \mathrm{Rh}-\mathrm{P}_{1}-\mathrm{C}_{2}, 108.22(7) ; \mathrm{O}_{2}-\mathrm{P}_{1}-\mathrm{O}_{3}, 103.86(7)$; $\mathrm{O}_{3}-\mathrm{P}_{1}-\mathrm{C}_{2}, 97.13(8) ; \mathrm{O}_{2}-\mathrm{P}_{1}-\mathrm{C}_{2}, 107.27(8)$.

temperature, and a clean yellow-brown powder was obtained (eq 1).

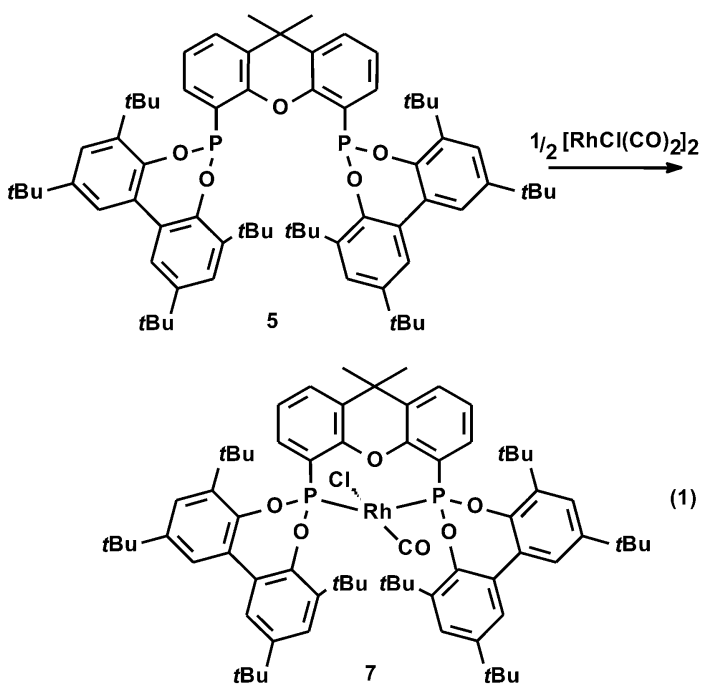

The 31P NMR spectrum showed only a doublet, indicative of a trans orientation of the two phosphorus atoms, giving rise to the formation of the complex trans$[\mathrm{Rh}(\mathrm{Cl})(\mathrm{CO})(\mathbf{5})]$, with a coupling constant J Rh-P of 192 $\mathrm{Hz}$. For their calix[4]arene-based diphosphonite system, Schmutzler and Börner claimed cis coordination of the bi dentate ligand in the complexes $[\mathrm{Rh}(\mathrm{nbd})(\mathrm{L})] \mathrm{BF}_{4}$ and $[\mathrm{Rh}(\operatorname{cod})(\mathrm{L})] \mathrm{BF}_{4}$ on the basis of the coupling constant $\mathrm{J}$ Rh-P of between 220 and $240 \mathrm{~Hz} .22$

In the IR spectrum (ATR mode) of the solid the CO stretching vibration was visible at $v_{\mathrm{CO}} 1999 \mathrm{~cm}^{-1}$. A full account of the coordination chemistry of these new ligands, which all show similar chelating behavior toward rhodium, is reported el sewhere. ${ }^{25}$ The actual value falls between those typical for $\mathrm{RhCl}(\mathrm{CO})$ (phosphite) complexes $\left(v_{\mathrm{CO}} \sim 2015 \mathrm{~cm}^{-1}\right)^{26}$ and $\mathrm{RhCl}(\mathrm{CO})$ (phosphinite) complexes $\left(v_{\text {co }} 1990 \mathrm{~cm}^{-1}\right){ }^{27}$

Crystal Structure of the Chlorocarbonylrhodium(I) Complex 7. The compound $[\mathrm{Rh}(\mathrm{Cl})(\mathrm{CO})(5)]$, complex 7, crystallized as yellow blocks from $\mathrm{CH}_{2} \mathrm{Cl}_{2} /$ $\mathrm{CH}_{3} \mathrm{CN}$, and the molecular structure was unequivocally established by X-ray crystallography. The molecular structure of complex $\mathbf{7}$ is depicted in Figure 3, together with data on selected bond lengths and angles for this complex, and it has the anticipated conformation of both phosphorus atoms trans to one another.

For complex 7, which has crystallographically imposed mirror symmetry, the geometry around the rhodium atom is clearly distorted square planar. This is shown in all angles around the rhodium atom. The $\mathrm{P}_{1}-\mathrm{Rh}-\mathrm{P}_{1 \mathrm{a}}$ bite angle is $149.40(2)^{\circ}$, while the $\mathrm{Cl}_{1}-\mathrm{Rh}-\mathrm{C}_{1}$ angle is $174.56(8)^{\circ}$. We attribute the small intramolecular $\mathrm{Rh}-\mathrm{O}_{4}$ distance of only $2.7091(17) \AA$, which is significantly smaller than the sum of both atomic radi i, to a weak interaction between the $\mathrm{Rh}$ atom and oxygen atom $\mathrm{O}_{4}$, which would lead to a squarepyramidal configuration. It is the first time that this interaction has been el uci dated for a nonionic rhodium complex of a xanthene-based ligand. ${ }^{28}$ The intramolecu-

(25) van der Vlugt, J . I.; Sablong, R.; Mills, A. M.; Kooijman, H.; Spek, A. L.; Meetsma, A.; Vogt, D. Dalton Trans. 2003, 4690.

(26) Fernández, E.; Ruiz, A.; Claver, C.; Castillón, S.; Polo, A.; Piniella, J . F.; Alvarez-Larena, A. Organometallics 1998, 17, 2857.

(27) (a) van der Vlugt, J . I .; Fioroni, M.; Ackerstaff, J .; Hanssen, R W. J. M.; Mills, A. M.; Kooijman, H.; Spek, A. L.; Meetsma, A. Abbenhuis, H. C. L.; Vogt, D. Organometallics 2003, 22, 5297 and references therein. (b) van der Slot, S. C.; Duran, J .; Luten, J .; Kamer, P. C. J .; van Leeuwen, P. W. N. M. Organometallics 2002, 21, 3873.

(28) For an ionic $\mathrm{Rh}$-phosphine complex with such an interaction, see: Sandee, A. J .; van der Veen, L. A.; Reek, J. N. H.; Kamer, P. C. J .; Lutz, M.; Spek, A. L.; van Leeuwen, P. W. N. M. Angew. Chem., Int. Ed. 1999, 38, 3231. 
Iar $\mathrm{P}_{1}-\mathrm{P}_{1 \mathrm{a}}$ distance is 4.3534(7) $\AA$. The $\mathrm{Cl}-\mathrm{Rh}-\mathrm{P}$ angles are all below $90^{\circ}$, while the $\mathrm{C}_{1}-\mathrm{Rh}-\mathrm{P}$ angles are all well above $90^{\circ}$. The $\mathrm{C}_{1}-\mathrm{O}_{1}$ bond length is normal at 1.142(4) Å. Furthermore, complex 7 can be considered as a structural model for the four-coordinate species $\left[\mathrm{Rh}(\mathrm{H})(\mathrm{CO})\left(\mathrm{P}^{-} \mathrm{P}\right)\right]^{29}$ formed in the catalytic cycle of hydroformylation by $\mathrm{CO}$ dissociation from the catalyst resting state $\left[\mathrm{Rh}(\mathrm{H})(\mathrm{CO})_{2}\left(\mathrm{P}^{-} \mathrm{P}\right)\right]($ eq 2$) .{ }^{30}$

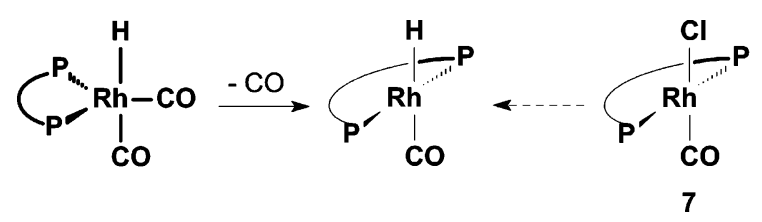

So far, no examples of molecular structures of [Rh$(\mathrm{Cl})(\mathrm{CO})\left(\mathrm{P}^{-} \mathrm{P}\right)$ ] complexes with diphosphonites have appeared in the literature; therefore, it is difficult to compare bond lengths found for these complexes. The group of Pastor has reported a [Rh(acac)diphosphonite] complex. ${ }^{31}$ Puddephatt has described the face-to-face dimer with a (CO) Rh- $\mathrm{Cl}-\mathrm{Rh}(\mathrm{CO})$ core and the ligand $(\mathrm{PhO})_{2} \mathrm{PCH}_{2} \mathrm{P}(\mathrm{OPh})_{2}{ }^{32}$ Their reported values for the $\mathrm{Rh}-\mathrm{Cl}$ and $\mathrm{Rh}-\mathrm{P}$ bond lengths are different compared to those found for complex 7, most likely due to the different electronic properties of the backbones used and the dimeric nature of their complex. Atherton has published the structural characterization of a $\mathrm{Rh}^{\text {III }}$ complex with a monodentate phosphonite, with bond lengths essentially similar to those above. ${ }^{33}$ The best al ternatives for comparison are similar complexes containing diphosphite ligands. In such structures with either mono- or bidentate ligands, normal $\mathrm{Rh}-\mathrm{P}$ bond lengths are around $2.15 \AA$, while the $\mathrm{Rh}-\mathrm{Cl}$ bond lengths are 2.36-2.37 $\AA$. For the carbonyl ligand, the $\mathrm{C}-\mathrm{O}$ bond length is $1.14 \AA$, on average. ${ }^{26,34,35}$ We have attempted to convert complex $\mathbf{7}$ to the corresponding hydrido species by substitution of the halide ligand with $\mathrm{LiB}\left(\mathrm{Et}_{3}\right)(\mathrm{H})$, commercially available as SuperHydride, but this reaction was unsuccessful. Previously, J ones used this reagent to obtain $\mathrm{Ni}(u-\mathrm{H})_{2}$ (dippe) (dippe = bis(dii isopropylphosphino)ethane) from $\mathrm{NiCl}_{2}$ (dippe), ${ }^{36}$ while Carmona and co-workers described the reaction of $\mathrm{MCl}_{2}-$ $(\mathrm{CO})_{2}\left(\mathrm{PMe}_{3}\right)_{3}(\mathrm{M}=\mathrm{W}$, $\mathrm{Mo})$ to give $\mathrm{MCl}(\mathrm{H})(\mathrm{CO})_{2^{-}}$ $\left(\mathrm{PMe}_{3}\right)_{3 .}{ }^{37}$ Four-coordinate $\left[\mathrm{Rh}(\mathrm{H})(\mathrm{CO})\left(\mathrm{P}^{-} \mathrm{P}\right)\right]$ complexes have rarely been observed. One significant contribution, with $\mathrm{P}^{-\mathrm{P}}$ being a cyclodextrin-derived di phosphine, was recently published by Engeldinger et al. ${ }^{38}$

(29) Freeman, M. A.; Young, D. A. Inorg. Chem. 1986, 25, 1556. 2660.

(30) Evans, D.; Yagulpsky, G.; Wilkinson, G. J . Chem. Soc. A 1968

(31) Shum, S. P.; Pastor, S. D.; Rihs, G. I norg. Chem. 2002, 41, 127. (32) Kumar, R.; Puddephatt, R. J .; Fronczek, F. R. Inorg. Chem. 1990, 29, 4850.

(33) Atherton, M. J .; Fawcett, J .; Hill, A. P.; Holloway, J . H.; Hope, E. G.; Russell, D. R.; Saunders, G. C.; Stead, R. M. J . J . Chem. Soc., Dalton Trans. 1997, 1137.

(34) Paciello, R.; Siggel, L.; Kneuper, H. J .; Walker, N.; Röper, M. J. Mol. Catal. A: Chem. 1999, 143, 85.

(35) (a) van den Beuken, E. K.; de Lange, W. G. J .; van Leeuwen, P. W. N. M.; Veldman, N.; Spek, A. L.; Feringa, B. L. J . Chem. Soc. Dalton Trans. 1996, 3561. (b) Cobley, C. J .; Ellis, D. D.; Orpen, A. G.; Pringle, P. G. J . Chem. Soc., Dalton Trans. 2000, 1109. (c) Suárez, A.; Méndez-Rojas, M. A.; Pizzano, A. Organometallics 2002, 21, 4611.

(36) Vicic, D. A.; J ones, W. D. J . Am. Chem. Soc. 1997, 119, 10855.

(37) Contreras, L.; Monge, A.; Pizzano, A.; Ruiz, C.; Sánchez, L.; Carmona, E. Organometallics 1993, 12, 4228.

(38) Engeldinger, E.; Armspach, D.; Matt, D. Chem. Eur. J . 2003, 9, 3091

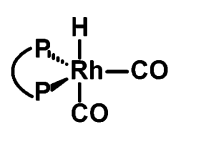

equatorial-equatorlal

ee

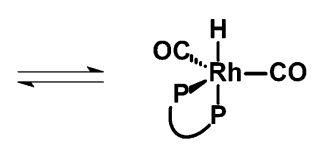

equatorial-apical

ea

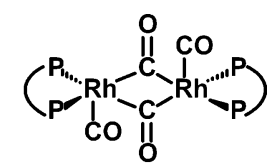

CO-bridged dimer
Figure 4.

Table 1. High Pressure in Situ NMR Data for $\mathbf{R h}(\mathrm{H})(\mathrm{CO})_{2}\left(\mathrm{P}^{-} \mathrm{P}\right)$ Complexes $^{\mathrm{a}}$

\begin{tabular}{|c|c|c|c|c|c|}
\hline ligand & $\begin{array}{c}\delta\left(^{31} \mathrm{P}\left\{{ }^{1} \mathrm{H}\right\}\right) \\
(\mathrm{ppm})\end{array}$ & $\begin{array}{l}\delta\left({ }^{1} \mathrm{H}\right) \\
\text { (ppm) }\end{array}$ & $\begin{array}{c}\mathrm{J} R \mathrm{Rh}-\mathrm{P} \\
(\mathrm{Hz})\end{array}$ & $\begin{array}{c}{ }^{1} \mathrm{~J}_{\mathrm{Rh}-\mathrm{H}} \\
(\mathrm{Hz})\end{array}$ & $\begin{array}{l}{ }^{2} \mathrm{P}-\mathrm{H} \\
(\mathrm{Hz})\end{array}$ \\
\hline 1 & 150.9 & -9.9 & 210.6 & 3.6 & 18.3 \\
\hline 2 & 157.4 & -9.9 & 195.2 & n.d. & n.d. \\
\hline 3 & 156.6 & -9.7 & 195.3 & n.d. & n.d. \\
\hline 4 & 165.5 & -9.8 & 207.5 & 2.5 & 23.2 \\
\hline 5 & 166.0 & -9.5 & 206.4 & 2.4 & 22.6 \\
\hline 6 & 164.8 & -9.7 & 206.4 & 3.2 & 22.4 \\
\hline
\end{tabular}

a Conditions: $1.5 \mathrm{~mL}$ of toluene- $\mathrm{d}_{8}, 5.0 \mathrm{mg}$ of $\mathrm{Rh}(\mathrm{acac})(\mathrm{CO})_{2}$ (19.4 $\mu \mathrm{mol})$, ligand: $\mathrm{Rh}=1.05: 1, \mathrm{p}=20$ bar of $\mathrm{H}_{2} / \mathrm{CO}(1: 1)$, preformation at $80^{\circ} \mathrm{C}$ for $1 \mathrm{~h}$, measured at room temperature.

High-Pressure NMR Spectroscopy. Since the actual coordination mode of the ligand during catalysis is bel ieved to play a central role in the control of regioselectivity, we were interested in investigating this point in more detail. It is well established that high-pressure NMR and IR measurements can aid in better understanding the preformation of the catalyst resting state, ${ }^{7,39-41}$ even though there are some differences in reaction conditions compared to those during catalysis. With high-pressure (HP) NMR spectroscopy it is possible to distinguish between three major species, as depicted in Figure 4. Usually CO-bridged dimers are only favored at high rhodium concentrations. ${ }^{42}$

$\mathrm{Rh}$ (acac)(CO) 2 was reacted with a slight excess of the appropriate ligand under 20 bar of $\mathrm{CO} / \mathrm{H}_{2}(1: 1)$, and the resulting ${ }^{1} \mathrm{H}$ and ${ }^{31} \mathrm{P}$ NMR spectra were recorded at room temperature. The results are listed in Table 1. There is a clear effect of the steric bulk of the ligand on the Rh complex formed, as can be seen from the NMR spectra obtained for the $\left[\mathrm{Rh}(\mathrm{H})(\mathrm{CO})_{2}\left(\mathrm{P}^{-} \mathrm{P}\right)\right]$ complexes. The flexible ligand $\mathbf{1}$ gives the most upfield signal, yet it has the highest J Rh-P coupling constant in the ${ }^{31} \mathrm{P}$ NMR spectrum. This is probably due to the bulky tertbutyl groups, which point toward the center of the complex (vide supra), leading to a slightly distorted trigonal bipyramidal geometry. For ligands $\mathbf{2}$ and $\mathbf{3}$, with less steric hindrance around the metal center (the bulky tert-butyl groups are directed away from the coordination site), smaller J Rh-P coupling constants are obtained.

With ligands 4-6 similar results were found, which is plausible, since these ligands are virtually identical

(39) Buisman, G. J . H.; van der Veen, L. A.; Kamer, P. C. J .; van Leeuwen, P. W. N. M. Organometallics 1997, 16, 5681.

(40) (a) Horváth, I. T.; Kastrup, V.; Oswald, A.; M ozeleski, J . Catal . Lett. 1989, 2, 85. (b) Moasser, B.; Gladfelter, W. L.; Roe, D. C. Organometallics 1995, 14, 3832. (c) Moasser, B.; Gladfelter, W. L Inorg. Chim. Acta 1996, 242, 125. (d) Bianchini, C.; Lee, H. M.; Meli, A.; Vizza, F. Organometallics 2000, 19, 849.

(41) Brown, J. M.; Kent, A. G. J . Chem. Soc. Perkin Trans. 2 1987, 1597

(42) (a) Pottier, Y.; Mortreux, A.; Petit, F. J . Organomet. Chem. 1989, 370, 333. (b) Castellanos-Páez, A.; Castillón, S.; Claver, C.; van Leeuwen, P. W. N. M.; de Lange, W. G. J . Organometallics 1998, 17, 2543. (c) Ewalds, R.; Eggeling, E. B.; Hewat, A. C.; Kamer, P. C. J .; van Leeuwen, P. W. N. M.; Vogt, D. Chem. Eur. J . 2000, 6, 1496. 
Table 2. High-Pressure in Situ IR Data for $\mathbf{R h}(\mathrm{H})(\mathrm{CO})_{2}\left(\mathrm{P}^{-} \mathrm{P}\right)$ Complexes $^{\mathrm{a}}$

\begin{tabular}{ccc}
\hline ligand & $v_{1}\left(\mathrm{~cm}^{-1}\right)$ & $v_{2}\left(\mathrm{~cm}^{-1}\right)$ \\
\hline $\mathbf{1}$ & 2017 & 2056 \\
$\mathbf{2}$ & 2000 & 2055 \\
$\mathbf{4}$ & 2000 & 2064 \\
$\mathbf{5}$ & 2001 & 2066
\end{tabular}

a Conditions: $50 \mathrm{~mL}$ autoclave, $15 \mathrm{~mL}$ of cyclohexane, $4.0 \mathrm{mg}$ of $\mathrm{Rh}(\mathrm{acac})(\mathrm{CO})_{2}(15.5 \mu \mathrm{mol})$, ligand: $\mathrm{Rh}=2: 1, \mathrm{p}=20$ bar of $\mathrm{H}_{2} /$ $\mathrm{CO}(1: 1), \mathrm{T}=80^{\circ} \mathrm{C}, 2 \mathrm{~h}$.

with regard to steric properties. In the hydride region of the ${ }^{1} \mathrm{H}$ NMR spectrum, a doublet of triplets is observed in all cases. From the measured coupling constants ${ }^{1} \mathrm{~J}_{\mathrm{Rh}-\mathrm{H}}$ of about $3 \mathrm{~Hz}$ and ${ }^{2} \mathrm{~J}_{\mathrm{P}-\mathrm{H}}$ in the range of $18-23 \mathrm{~Hz}$, it is evident that the diphosphoniteligands coordinate predominantly in an equatorial-equatorial (ee) fashion. An equatorial-axial coordination would lead to much higher coupling constants, due to the trans influence of the phosphorus atom $\mathrm{P}_{\mathrm{ax}}$, as seen with related phosphite systems. ${ }^{39}$

High-Pressure IR Spectroscopy. For additional information on the complexation behavior, IR spectra of the $\mathrm{Rh}(\mathrm{H})(\mathrm{CO})_{2}\left(\mathrm{P}^{-} \mathrm{P}\right)$ complexes were recorded under 20 bar of syngas. The results of these experiments are listed in Table 2. If a rapid fluxional process would occur due to the existence of an ee:ea equilibrium, four absorption bands should be visible, as described by Brown and Kent for $\mathrm{Rh}(\mathrm{H})(\mathrm{CO})_{2}\left(\mathrm{PPh}_{3}\right)_{2} \cdot{ }^{41}$ However, only two absorption bands of equal intensity are present in the carbonyl region of the spectrum, which supports the conclusion that the ee conformation exists predominantly in solution for $\mathrm{Rh}(\mathrm{H})(\mathrm{CO})_{2}\left(\mathrm{P}^{-} \mathrm{P}\right)$.

Rhodium-Catalyzed Hydroformylation. As a benchmark reaction, ligands $\mathbf{1 - 6}$ were tested in the rhodium-catalyzed hydroformylation of 1-octene (eq 3).
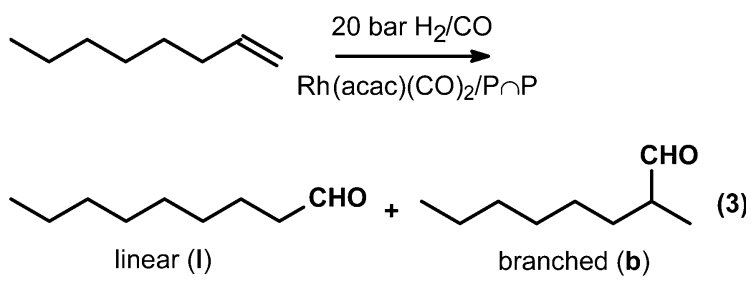

Reactions were carried out under typical hydroformylation conditions, at 20 bar of syngas (CO: $\left.\mathrm{H}_{2}=1: 1\right)$ and $80^{\circ} \mathrm{C}$, using $\mathrm{Rh}(\mathrm{CO})_{2}$ (acac) (acac = acetylacetonate) and 6 equiv of ligand. Conversions were kept below 30\% in order to be able to give meaningful TOF values. Complete conversions could be reached after prolonged reaction times. The results of these catalytic runs are listed in Table 3.

Especially the more flexible diphosphonites $\mathbf{2}$ and $\mathbf{3}$, based on 3,5-di-tert-butylphenol, give high activities along with good selectivities to the desired linear aldehyde. With the more bulky ligands 1 and especially with 4-6, significantly lower activities and slightly lower selectivities to the desired 1-nonanal are obtained. The amount of isomerization of the starting material is somewhat higher than with catalysts containing xanthene-based diphosphines. ${ }^{43}$ Whether this is due to electronic or steric effects is not clear. There seems to be a small difference between the xanthene and the phenoxathiin backbone, comparing the results obtained
Table 3. Rhodium-Catalyzed Hydroformylation of 1-Octene Using Diphosphonite Ligandsa

\begin{tabular}{cccccccc}
\hline ligand & $\begin{array}{c}\text { time } \\
(\mathrm{h})\end{array}$ & $\begin{array}{c}\text { con- } \\
\text { versn } \\
(\%)^{c}\end{array}$ & $\begin{array}{c}\text { selec- } \\
\text { tivity } \\
(\%)^{\mathrm{b}, \mathrm{c}}\end{array}$ & $\begin{array}{c}\text { isomer- } \\
\text { ization } \\
(\%)^{\mathrm{c}}\end{array}$ & $\begin{array}{c}\text { hydrog- } \\
\text { enation } \\
(\%)^{c}\end{array}$ & $\begin{array}{c}\text { I:b } \\
\text { ratioc }\end{array}$ & $\begin{array}{c}\text { TOF }^{\mathrm{d}} \\
\left(\mathrm{h}^{-1}\right)\end{array}$ \\
\hline $\mathbf{1}$ & 2.5 & 24.8 & 92.9 & 6.0 & 1.1 & 8.9 & 256 \\
$\mathbf{2}$ & 1.5 & 31.4 & 93.2 & 6.5 & 0.3 & 6.7 & 530 \\
$\mathbf{3}$ & 1.5 & 27.4 & 93.5 & 6.2 & 0.3 & 7.7 & 419 \\
$\mathbf{4}$ & 2.5 & 18.4 & 96.6 & 1.9 & 1.5 & 7.4 & 181 \\
$\mathbf{5}$ & 2.5 & 12.7 & 96.8 & 2.0 & 1.1 & 4.8 & 127 \\
$\mathbf{6}$ & 2.5 & 15.9 & 95.7 & 3.3 & 1.0 & 5.1 & 160
\end{tabular}

a Reactions were carried out in a $75 \mathrm{~mL}$ autoclave. Conditions: 1-octene $(23.7 \mathrm{mmol})$, decane $(9.6 \mathrm{mmol})$, toluene $(14.5 \mathrm{~mL}), \mathrm{T}=$ $80{ }^{\circ} \mathrm{C}, \mathrm{p}=20$ bar, $\left[\mathrm{Rh}(\mathrm{acac})(\mathrm{CO})_{2}\right]=0.47 \mathrm{mM}$, substrate: $\mathrm{Rh}=$ 2500:1, ligand:Rh $=6: 1,1 \mathrm{~h}$ preformation. ${ }^{\mathrm{b}}$ Selectivity to aldehydes. ' ${ }^{c}$ Determined by GC analysis. ${ }^{d}$ Defined as mol of substrate converted (mol of $\mathrm{Rh})^{-1} \mathrm{~h}^{-1}$.

with ligands $\mathbf{2}$ and $\mathbf{3}$. A possible explanation for this apparent difference in activity could be a slight distortion or flipping motion of the phenoxathiin backbone in the catalyst complex, as found by Goertz et al. ${ }^{44}$ The activities obtained with these rhodium diphosphonite systems are higher than for the related diphosphine ligands (generally termed Xantphos), ) ${ }^{19 c, 43}$ and while the regioselectivies are generally lower than with the corresponding diphosphines and diphosphites, they outperform the previously reported diphosphonite ligands. ${ }^{22}$

Industrial feedstocks such as Raffinate II from cracking facilities ${ }^{4,45}$ constitute a mixture of unsaturated $C_{4}$ compounds. Such substrate "cocktails" would be interesting candidates if suitable catalysts could be developed which sel ectively produce terminal aldehydes from such internal al kenes. The ultimate catalyst needed for this reaction therefore has to combine a very high isomerization activity with a high preference for terminal alkenes and a high regioselectivity for the linear aldehyde in the hydroformylation step. ${ }^{34}$ Only very recently novel Rh systems which are able to convert internal alkenes, e.g. 2-pentene or 4-octene, to the desired linear products have been published. ${ }^{23,46-48}$ Structure prediction for ligands which induce n-sel ectivity in combination with isomerization activity is still nonexistent. In general, the Rh-based hydroformylation catalysts reported so far unfortunately show only low isomerization rates-except for some remarkable diphosphite systems ${ }^{49}$-leaving this field mainly to the classic Co systems, which on the other hand suffer from unwanted parallel and side reactions. 5,50

(43) van der Veen, L. A.; Keeven, P. H.; Schoemaker, G. C.; Reek, J . N. H.; Kamer, P. C. J .; van Leeuwen, P. W. N. M.; Lutz, M.; Spek, A. L. Organometallics 2000, 19, 872.

(44) Goertz, W.; Keim, W.; Vogt, D.; Englert, U.; Boele, M. D. K. van der Veen, L. A.; Kamer, P. C. J .; van Leeuwen, P. W. N. M. J. Chem. Soc., Dalton Trans. 1998, 2981.

(45) Vogt, D. In Applied Homogeneous Catalysis with Organometallic Compounds; Cornils, B., Herrmann, W. A., Eds.; Wiley-VCH: Weinheim, Germany, 2002; Vol. 1, p 240.

(46) (a) Bronger, R. P. J .; Kamer, P. C. J .; van Leeuwen, P. W. N. M. Organometallics 2003, 22, 5358. (b) van der Veen, L. A.; Kamer, P. C. J .; van Leeuwen, P. W. N. M. Angew. Chem., Int. Ed. 1999, 38, 336. (47) Selent, D.; Hess, D.; Wiese, K.-D.; Röttger, D.; Kunze, C.; Börner, A. Angew. Chem., Int. Ed. 2001, 40, 1696.

(48) Klein, H.; J ackstell, R.; Wiese, K.-D.; Borgmann, C.; Beller, M. Angew. Chem., Int. Ed. 2001, 40, 3408.

(49) (a) Billig, E.; Abatjoglou, A. G.; Bryant, D. R. (to Union Carbide) Eur. Patent 213,639, 1987; Chem. Abstr. 1987, 107, 7392. (b) Billig E.; Abatjoglou, A. G.; Bryant, D. R. (to Union Carbide) Eur. Patent 214,622, 1987; Chem. Abstr. 1987, 107, 25126. (c) Burke, P. M.; Garner, J . M.; Tam, W.; Kreutzer, K. A.; Teunissen, A. J . J . (to Du Pont/DSM) WO 97/33,854, 1997; Chem. Abstr. 1997, 127, 294939. 
<smiles>O=C(O)Cc1ccc2ccccc2c1-c1c(CCc2ccccc2)ccc2ccccc12</smiles>

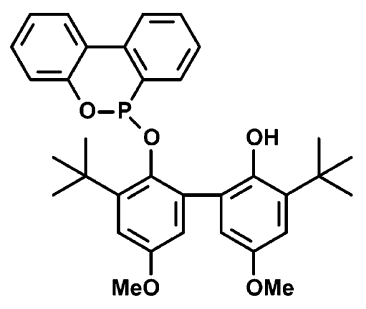

9<smiles>Cc1cc(F)cc(F)c1</smiles>

$\operatorname{Ar}=$
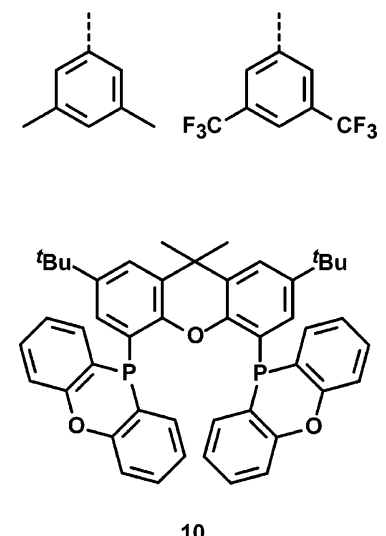

Figure 5.

On the basis of the promising results obtained with 1-octene as the substrate, we decided to test ligand $\mathbf{2}$ in the rhodium-catalyzed isomerizing hydroformylation of 2-butene to get some preliminary idea of its potential. Reaction conditions were modified to limit the direct hydroformylation of internal alkenes and favor isomerization toward the terminal alkene. At a reaction temperature of $120{ }^{\circ} \mathrm{C}, 6$ bar of syngas, and a ligandto-rhodium ratio of 5:1 the conversion was $9 \%$ after $4 \mathrm{~h}$ of reaction, with a turnover frequency of $343 \mathrm{~h}^{-1}$ (2-butene:rhodium ratio of 15 250:1). The chemoselectivity to aldehydes is high at $90 \%$, while the regioselectivity to the desired pentanal was surprisingly high at $61 \%$. With a higher ligand-to-rhodium ratio (10:1) and a temperature of $140{ }^{\circ} \mathrm{C}$ the conversion increased to $66 \%$, with a turnover frequency of $2516 \mathrm{~h}^{-1}$. The chemoselectivity remained high at $94 \%$ to aldehydes, and the regioselectivity stayed constant with an $1: b$ ratio of 62:38.

These prelimi nary results are among the best known in the open literature for the hydroformylation of the challenging substrate 2-butene. Electron-deficient diphosphines based on the NAPHOS structure (8; Figure 5) have been reported to give I:b ratios of up to $95: 5$ and TOF's of up to $900 \mathrm{~h}^{-1} .48$ Unfortunately, nothing was reported about the hydrogenation side reaction with these systems. For the production of n-nonanal from isomeric n-octenes using monophosphonite $\mathbf{9}$, Börner et al. reported I:b ratios of $48: 52$ at the maximum, with corresponding TOF's of up to $2840 .{ }^{23}$ Van Leeuwen et al. obtained turnover frequencies up to $112 \mathrm{~h}^{-1}$ for 2-octene and I:b ratios up to 95:5 with phosphacyclic diphosphines $\mathbf{1 0}$ derived from xanthene. ${ }^{46}$

From the comparison with previously developed ligand systems we conclude that our novel diphosphonite ligands form rhodium complexes that are very efficient for the hydroformylation of terminal alkenes, e.g. 1-octene, and for the selective isomerizing hydroformylation of internal alkenes such as 2-butene. This opens up new applications for industrial feedstocks such as

(50) Beller, M.; Krauter, J . G. E. J . Mol. Catal. A: Chem. 1999, 143,
Raffinate II and other internal alkenes. It should be noted that the diphosphonite moiety can be easily varied over a wide range concerning sterics and el ectronics, ${ }^{51}$ and we are currently probing further modification and utilization of these ligands to expand their application in homogeneous catalysis.

\section{Conclusions}

We have reported on the coordination chemistry of novel sterically demanding xanthene-based diphosphoniteligands $\mathbf{1}-\mathbf{6}$ with rhodium. Complex 7, trans-[RhCl(CO)(5)], was structurally characterized by NMR and IR spectroscopy as well as by X-ray crystallography. There is a weak interaction between the rhodium center and the oxygen functionality in the xanthene backbone. In situ NMR and IR spectroscopy under syngas pressure showed that these diphosphonite ligands coordinate in a bis-equatorial fashion in the resting state of the catalytically active rhodium hydride species $[\mathrm{Rh}(\mathrm{H})(\mathrm{CO})$ $\left(\mathrm{P}^{-\mathrm{P})}\right)$. We have demonstrated the successful application of these diphosphonite ligands in the rhodiumcatalyzed hydroformylation. High activities were obtained for 1-octene, with good selectivity to the linear al dehyde. For the isomerizing hydroformylation of 2-butene with ligand 2, n-pentanal could be obtained in selectivities of up to $62 \%$. We expect that the modular character of this class of diphosphonite ligands makes them ideally suited for further catalytic investigations, which are currently in progress.

\section{Experimental Section}

General Considerations. All chemicals were purchased from Aldrich, Acros, or Merck. Synthesis gas $\left(\mathrm{CO} / \mathrm{H}_{2} 1: 1\right)$ was purchased from Hoekloos. All preparations were carried out under an argon atmosphere using standard Schlenk techniques. Solvents were distilled from sodium/benzophenone (2Me-THF, toluene, toluene- $\left.\mathrm{d}_{8}\right)$ or calcium hydride $\left(\mathrm{CH}_{2} \mathrm{Cl}_{2}\right.$, $\mathrm{CH}_{3} \mathrm{CN}$, and $\mathrm{CDCl}_{3}$ ) prior to use. All glassware was dried by heating under vacuum. The NMR spectra were recorded on a Varian Mercury 400 spectrometer. Chemical shifts are given in ppm referenced to solvent $\left({ }^{1} \mathrm{H},{ }^{13} \mathrm{C}\left\{{ }^{1} \mathrm{H}\right\}\right)$ or an $85 \%$ aque ous solution of $\mathrm{H}_{3} \mathrm{PO}_{4}\left({ }^{31} \mathrm{P}\left\{{ }^{1} \mathrm{H}\right\}\right)$. Part of the high-pressure NMR spectra were recorded on a Bruker $200 \mathrm{MHz}$ spectrometer. High-pressure IR spectra were recorded on a Shimadzu FTIR 8300 spectrometer. Elemental analysis was performed by Kolbe Mikroanalytisches Laboratorium, Muel heim an der Ruhr, Germany. IR spectra were taken on an AVATAR E.S.P. 360 FTIR spectrometer. GC spectra were recorded on a Shimadzu 17A chromatograph equipped with a PONA column. Ligands 1-6 were prepared in our laboratories and have been reported by Hewat.20a,24b

trans-[Rh(Cl)(CO)(5)] (7). Both $\left[\mathrm{Rh}(\mu-\mathrm{Cl})(\mathrm{CO})_{2}\right]_{2}(44.4 \mathrm{mg}$, $114.2 \mu \mathrm{mol}$ ) and ligand $\mathbf{5}$ (248.7 mg, $228.7 \mu \mathrm{mol}$ ) were dissolved in $10 \mathrm{~mL}$ of dichloromethane, and the solution was stirred overnight at room temperature. The solvent was then removed in vacuo to give a yellow solid. Crystals suitable for $\mathrm{X}$-ray analysis were obtained by layering a solution of $\mathbf{7}$ in $\mathrm{CH}_{2} \mathrm{Cl}_{2}$ with $\mathrm{CH}_{3} \mathrm{CN} .{ }^{1} \mathrm{H} \mathrm{NMR}\left(\mathrm{CDCl}_{3}\right): \delta 7.58\left(\mathrm{~d}, 2 \mathrm{H},{ }^{1} \mathrm{~J}=8.0 \mathrm{~Hz}\right)$, $7.50\left(\mathrm{dd}, 2 \mathrm{H},{ }^{1} \mathrm{~J}=7.6 \mathrm{~Hz},{ }^{2} \mathrm{~J}=1.6 \mathrm{~Hz}\right), 7.34\left(\mathrm{~d}, 2 \mathrm{H},{ }^{1} \mathrm{~J}=2.8\right.$ $\mathrm{Hz}), 7.22\left(\mathrm{~d}, 2 \mathrm{H},{ }^{1} \mathrm{~J}=2.8 \mathrm{~Hz}\right), 7.02(\mathrm{~m}, 3 \mathrm{H}), 6.79\left(\mathrm{t}, 3 \mathrm{H},{ }^{1} \mathrm{~J}=\right.$ $7.6 \mathrm{~Hz}), 1.78\left(\mathrm{~s}, 3 \mathrm{H}, \mathrm{CCH}_{3}\right), 1.64\left(\mathrm{~s}, 18 \mathrm{H}, \mathrm{C}\left(\mathrm{CH}_{3}\right)_{3}\right), 1.44(\mathrm{~s}$, $\left.18 \mathrm{H}, \mathrm{C}\left(\mathrm{CH}_{3}\right)_{3}\right), 1.40\left(\mathrm{~s}, 18 \mathrm{H}, \mathrm{C}\left(\mathrm{CH}_{3}\right)_{3}\right), 1.32\left(\mathrm{~s}, 3 \mathrm{H}, \mathrm{CCH}_{3}\right), 1.23$ $\left(\mathrm{s}, 18 \mathrm{H}, \mathrm{C}\left(\mathrm{CH}_{3}\right)_{3}\right) .{ }^{13} \mathrm{C}\left\{{ }^{1} \mathrm{H}\right\} \mathrm{NMR}\left(\mathrm{CDCl}_{3}\right): \delta 153.8,149.8,147.6$, $146.9,143.0,142.2,139.9,136.3,132.4,129.3\left(d,{ }^{1} \mathrm{p}-\mathrm{C}=24.6\right.$

(51) Ahlers, W.; Paciello, R.; Vogt, D.; Hofmann, P. (to BASF AG) WO 02/83695, 2002; Chem. Abstr. 2002, 137, 311033. 
$\mathrm{Hz}), 127.0,126.7,125.3,125.0\left(\mathrm{~d},{ }^{1} \mathrm{p}-\mathrm{C}=10.5 \mathrm{~Hz}\right), 122.5$, $122.4,35.9,35.3\left(\mathrm{~d},{ }^{1} \mathrm{~J} \mathrm{p}-\mathrm{c}=6.5 \mathrm{~Hz}\right), 34.7\left(\mathrm{~d},{ }^{1} \mathrm{~J} \mathrm{p}-\mathrm{c}=4.6 \mathrm{~Hz}\right)$, 32.2, 31.7, 31.6, 31.5, 29.7. ${ }^{31} \mathrm{P}\left\{{ }^{1} \mathrm{H}\right\} \mathrm{NMR}\left(\mathrm{CDCl}_{3}\right) \delta 163.9(\mathrm{~s}$, 1] $=191.5 \mathrm{~Hz}$ ). FTIR (ATR mode, solid, $\left.\mathrm{cm}^{-1}\right): v 1999(\mathrm{Rh}-$ (CO)). Anal. Calcd for $\mathrm{C}_{72} \mathrm{H}_{92} \mathrm{ClO}_{6} \mathrm{P}_{2} \mathrm{Rh}$ : C, 68.97; $\mathrm{H}, 7.40$. Found: C, 69.13; $\mathrm{H}, 7.51$.

High-Pressure NMR Experiments. Measurements were performed in a $10 \mathrm{~mm}$ o.d. sapphire NMR tube, a homemade improvement of the design described by EIsevier. ${ }^{52}$ I $n$ a typical experiment $\mathrm{Rh}(\mathrm{acac})(\mathrm{CO})_{2}(5 \mathrm{mg}, 19.4 \mu \mathrm{mol})$ and 1.05 equiv of ligand were dissolved in $1.5 \mathrm{~mL}$ of toluene- $\mathrm{d}_{8}$. The solution was transferred into an argon-flushed tube. The tube was then flushed four times with 4 bar of synthesis gas and then pressurized to $20 \mathrm{bar}$. Preformation was carried out at $60^{\circ} \mathrm{C}$ for $16 \mathrm{~h}$, after which the tube was cooled to room temperature and the desired spectra were recorded. Alternatively, the chamber of a $10 \mathrm{~mL}$ autoclave was brought under an argon atmosphere, after which the aforementioned solution was injected by syringe. After preformation at $80^{\circ} \mathrm{C}$ for $1 \mathrm{~h}$ under stirring, the autoclave was depressurized, the contents were transferred into an NMR tube, and the spectra were recorded at room temperature.

High-Pressure IR Experiments. Measurements were performed using a homemade $50 \mathrm{~mL}$ stainless steel autoclave with an integrated flow cell equipped with ZnS windows, a mechanical stirrer, and temperature control. Prior to use argon was flushed through the apparatus for $2 \mathrm{~h}$. The catalyst mixture, containing $\mathrm{Rh}(\mathrm{acac})(\mathrm{CO})_{2}(4 \mathrm{mg}, 15.5 \mu \mathrm{mol})$ and ligand (2 equiv) in $15 \mathrm{~mL}$ of cyclohexane, was brought into the autoclave under a stream of argon. The solution was flushed 3 times with 4 bar of synthesis gas before pressurizing to $17 \mathrm{bar}$ at room temperature. The autoclave was then heated to $80{ }^{\circ} \mathrm{C}$ and spectra were recorded every $10 \mathrm{~min}$ for $2 \mathrm{~h}$.

Hydroformylation of 1-Octene. Reactions were performed using a $75 \mathrm{~mL}$ homemade autoclave equipped with an inner glass beaker. 1-Octene was filtered over neutral alumina prior to use to remove peroxides. In a typical experiment, Rh(acac) $(\mathrm{CO})_{2}(2.4 \mathrm{mg}, 9.3 \mu \mathrm{mol})$ and the appropriate amount of ligand (6 equiv) were each dissolved in $6 \mathrm{~mL}$ of toluene. The combined solutions were transferred under argon into the preheated autoclave $\left(80^{\circ} \mathrm{C}\right)$. The autoclave was then pressurized to 18 bar. After $1 \mathrm{~h}$ the substrate solution, containing 1-octene (3.7 mL, $23.7 \mathrm{mmol})$ and decane $(1.8 \mathrm{~mL}, 9.2 \mathrm{mmol})$ in toluene $(2.6 \mathrm{~mL})$, was added. After reaction the autoclave was cooled and the reaction mixture quenched by addition of an excess of $\mathrm{P}(\mathrm{OEt})_{3}$ to form inactive rhodium species. A sample was withdrawn for GC analysis.

Hydroformylation of 2-Butene. Reactions were performed in $300 \mathrm{~mL}$ autodaves. Typically, Rh(acac)(CO) 2 (3.0 mg, $11.6 \mu \mathrm{mol}$ ) and the appropriate amount of ligand (5 equiv) were each dissolved in $5.8 \mathrm{~mL}$ of toluene and added to the autoclave under argon. The active catalyst was preformed under 10 bar of synthesis gas at $140{ }^{\circ} \mathrm{C}$. After $30 \mathrm{~min}$ the autoclave was cooled and opened and 2-butene $(9.99 \mathrm{~g}, 178 \mathrm{mmol}$ ) was added. At room temperature 5 bar of synthesis gas was applied and the autoclave was subsequently heated to the desired temperature while the pressure was kept constant. After reaction the volatiles were recovered in a cold trap. A sample was withdrawn for GC analysis.

Crystal Structure Determination. Intensity data were collected on a N onius KappaCCD diffractometer. The structure was solved by automated Patterson methods using DIRDIF 9953
Table 4. Selected Crystallographic Data for Complex 7

\begin{tabular}{|c|c|}
\hline $\begin{array}{l}\text { formula } \\
\text { fw } \\
\text { cryst size }(\mathrm{mm}) \\
\text { cryst syst } \\
\text { space group } \\
\text { a }(\AA) \\
\mathrm{b}(\AA) \\
\mathrm{c}(\AA) \\
\mathrm{V}\left(\AA^{3}\right) \\
\mathrm{Z} \\
\mathrm{d}_{\text {calcd }}\left(\mathrm{g} \mathrm{cm}^{-3}\right) \\
\mu(\mathrm{MoK} \alpha)\left(\mathrm{mm}^{-1}\right) \\
\mathrm{T}(\mathrm{K}) \\
\text { total no. of rflns } \\
\text { no. of unique rflns }\left(\mathrm{R}_{\text {int }}\right)^{\mathrm{a}} \\
\text { wR2(F') (all data) } \\
\lambda(\AA) \\
\mathrm{R} 1(\mathrm{I}>2 \sigma(\mathrm{I}))^{\mathrm{c}} \\
\mathrm{F}(000)\end{array}$ & $\begin{array}{l}\mathrm{C}_{72} \mathrm{H}_{92} \mathrm{ClO}_{6} \mathrm{P}_{2} \mathrm{Rh} \\
1253.76 \\
0.10 \times 0.17 \times 0.28 \\
\text { orthorhombic } \\
\mathrm{Pnma}(\mathrm{No} .62) \\
20.7367(2) \\
30.4055(3) \\
12.5622(1) \\
7920.59(13) \\
4 \\
1.051 \\
0.332 \\
150 \\
65862 \\
9217(0.062) \\
0.1148 \\
0.71073 \\
0.0391 \\
2656\end{array}$ \\
\hline
\end{tabular}

and refined on $\mathrm{F}^{2}$ using SHELXL $97 .{ }^{54}$ The crystal structure contains voids ( $1974.5 \AA 3 /$ unit cell) filled with disordered solvent molecules (dichloromethane/acetonitrile). Their contribution to the structure factors was ascertained using PLATON/SQUEEZE (192 e/unit cell). ${ }^{55}$ All non-hydrogen atoms were refined with anisotropic displacement parameters. Structure validation and molecular graphics preparation were performed with the PLATON package. ${ }^{55}$ Selected crystallographic data are given in Table 4. CCDC-224585 contains the supplementary crystallographic data for this paper. These data can be obtained free of charge via www.ccdc.cam.ac.uk/ conts/retrieving.html (or from the Cambridge Crystallographic Data Centre, 12 Union Road, Cambridge CB2 1EZ, U.K.; fax (+44) 1223-336-033 and email deposit@ccdc.cam.uk).

Acknowledgment. This work has been financially supported by the National Research School Combination on Catalysis (NRSCC), BASF AG, and in part (A.M.M. and A.L.S.) by The Netherlands Organization for Scientific Research (CW-NWO). OMG is thanked for a generous loan of $\mathrm{Rh}(\mathrm{acac})(\mathrm{CO})_{2}$. We are indebted to Ton Staring and Eugène van Oers (TU/e) for technical assistance. Dr. Wolfgang Ahlers and Dr. Rocco Paciello (BASF AG) and Dr. Christian Müller (TU/e) are thanked for scientific discussions.

Supporting Information Available: Tables giving detailed information about the X-ray crystal structure analysis of 7; these data are al so available as a CIF file. This material is available free of charge via the Internet at http://pubs.acs.org.

\section{OM0498899}

(52) Elsevier, C. J . J . Mol. Catal. 1994, 92, 285.

(53) Beurskens, P. T.; Beurskens, G.; de Gelder, R.; García-Granda, S.: Gould, R. O.; Israël, R.; Smits, J. M. M., The DIRDIF 99 Program System; University of Nijmegen, Nijmegen, The Netherlands, 1999. (54) Sheldrick, G. M., SHELXL 97; U niversity of Göttingen, Göttingen, Germany, 1997.

(55) Spek, A. L. J . Appl. Crystallogr. 2003, 36, 7. 